\title{
MAGYAR ÁSATÁSOK IRAKI KURDISZTÁN HEGYEI KÖZÖTT. Az ELTE BTK kutatásai Grd-i Tle lelóhelyén (Rania-síkság)
}

\section{Kalla Gábor - Dezsố TAMás}

Magyar Régészet 8. évf. (2019), 4. szám, pp. 1-11. doi: https://doi.org/10.36245/mr.2019.4.4

Az ELTE BTK Kurdisztáni Expediciója Dezsö Tamás és Kalla Gábor vezetésével 2016 óta végez terepmunkát Grd-i Tle tell településén. A legalább kilencezer éves elözményekre visszanyúló domb Irak Kurdisztán Autonóm Tartományában, a hegyekkel körülzárt Rania-síkságon fekszik, és egyike a térség legfontosabb régészeti lelőhelyeinek. Az eddigi négy egyhónapos ásatási évad alatt sikerült a kiterjedt település alapvetö topográfiai viszonyait és a központjában fekvö tell kialakulásának számos körülményét, ill. korszakát meghatározni. Fontos iszlám és hellénisztikus-pártus kori emlékek feltárásán túl az elözetes feltételezés beigazolódott, miszerint az Újasszír Birodalom egyik fontos helyi igazgatási központját rejti a 30 méter magas domb.

\section{AZ ÁSATÁS CÉLJA ÉS A HELYSZIIN KIVÁLASZTÁSA}

A kutatási program fő célkitüzése az Újasszír Birodalom (Kr. e. 9-7. század) egy periférián fekvő igazgatási központjának kutatása volt. Egy birodalom müködését ugyanis csak akkor érthetjük meg, ha látjuk, hogy annak kialakulása és terjeszkedése milyen változásokat hozott a magterületeken és az elfoglalt régiókban egyaránt. Bár asszír provinciális székhelyeket már korábban is vizsgáltak, ezek szinte teljes mértékben a birodalom nyugati részében fekszenek (MACGInNIS, Wicke \& GREENFIELD 2016). A keleti határvidékeit öt évvel ezelöttig régészeti szempontból alig kutatták, és emiatt az írásos szövegekből ismert helységnevek azonosítása is nagy nehézségbe ütközik. Pedig ez a térség volt a birodalom egyik legfontosabb határvidéke, amely a magas hegységek túloldalán élő ellenséges népek elleni védelem mellett fontos szerepet játszott a hadsereg utánpótlásában és a magterületek ellátásában is. Grd-i Tle lelőhelye több szempontból is alkalmasnak tünt egy ilyen vizsgálatra. A környezetéből látványosan kiemelkedő domb uralja a termékeny Rania-síkság északnyugati részét (1. kép), és a felszínen található újasszír kori cserepek korabeli használatra utaltak. 2016-ban még folyt a háború az Iszlám Állam fegyveresei és iraki Kurdisztán pesmerga hadereje között, így a biztonsági szempontok is azt követelték meg, hogy a frontvonaltól távolabbi helyszínt válasszunk.

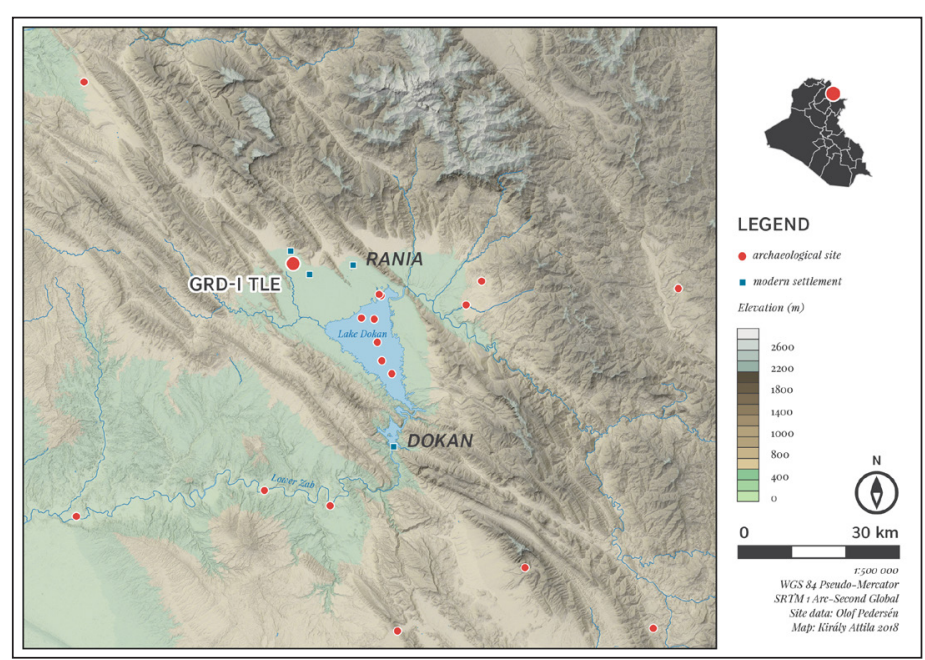

1. kép. Grd-i Tle lelöhely elhelyezkedése a Rania-síkságon. A Dokán-tó az ókorban nem létezett, az 1950-es években épült gát következményeként alakult ki, amely az Alsó Záb folyó vizét duzzasztotta fel. A jelzett lelöhelyek ekkor kerültek víz alá.

\section{GRD-I TLE TOPOGRÁFIÁJA}

A terepmunka 2016 szeptemberében egy geodéziai felméréssel kezdödött, melynek során elkészült az a $10 \times 10$ méteres négyzetháló, amely lefedte az egész lelőhelyet, és amelyhez a megnyitott szelvények igazodtak (2. kép). ${ }^{1}$ Az elkészült 3D modell alapján kiderült, hogy a domb nagyjából 30 méterrel emelkedik

\footnotetext{
1 A topográfiai felmérés Weisz Attila (Salisbury Kft.) munkája volt. A Salisbury Kft. számos más segítséget nyújtott az ásatásunkhoz.
} 
Kalla Gábor - Dezsö Tamás • Magyar ásatások iraki Kurdisztán hegyei között

az alsó város fölé, az ovális felső plató mai kiterjedése pedig 76×86 méter. Alatta, nagyjából 10-12 méter magasságban egy változó szélességű (10-25 méter) középső terasz fut, melynek nyugati részét a domb oldalába vágott modern út már elpusztította. A felső teraszon látható felszíni formákból, a rendkívül meredek domboldalból, valamint az út által vágott metszetből már a kutatás kezdetén egyértelmüen kiderült, hogy a tell tetején több egymást követő időszak erődítménye állt. Az egész dombot nagy mennyiségü kő borítja.

A domb alatti, 250×210 méter kiterjedésü alsó várost egy, a felszínen ma is jól látható ovális fal veszi körül, melynek maradványait ma csatornaként használják fel, illetve hozzá tartozik egy legalább 600×400 méter kiterjedésü külső város.

A geodéziai felmérést kiegészítette egy fémkereső müszeres vizsgálat, melynek során nagy menynyiségben kerültek elő 17-18. századi érmék és ékszerek. ${ }^{2}$ Mindez megerősítette azt a tényt, ami már az előzetes felmérésekből kiderült, hogy a lelöhely egészét a késő iszlám kori rétegek fedik.

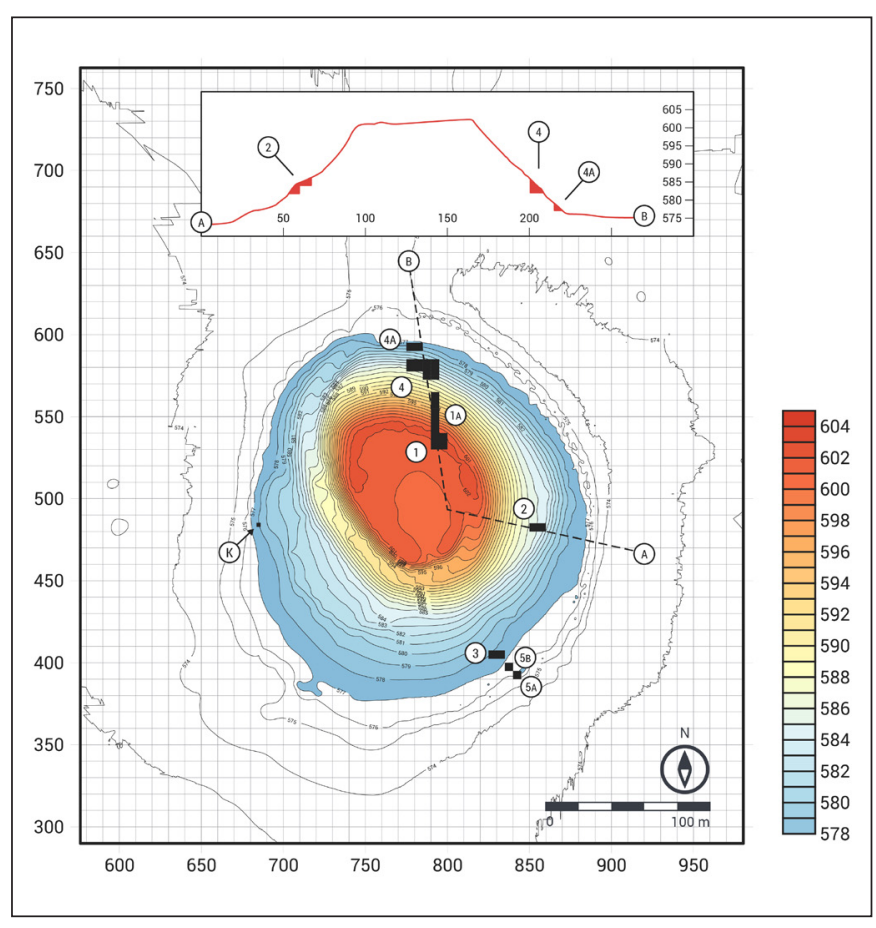

2. kép. A lelöhely szintvonalas térképe az egyes eddig kibontott felszinekkel. A 4. felszín tartalmazza a 4. mellett a 4B, 4C és 4D szelvényeket is. A metszetrajz jól mutatja a domb meredekségét.

\section{A LELÖHELY KORSZAKAI}

A négy évad folyamán összesen öt felszínen és tizenkét négyzetben végzett ásatások folyamán a település történetének és a lelőhely képződésének számos eleme vált világossá (2-3. kép). Bár még nem értük el az öskori szinteket, a felszíni darabok és a későbbi rétegekben nagy mennyiségben belekerült leletek alapján kiderült, hogy a tell kezdetei legalább a khalkolitikus Halaf-kultúra időszakáig nyúlnak viszsza (Kr. e. 6. évezred), lakott volt az Ubaid-korban (Kr. e. 5 évezred -4 . évezred első fele), valamint az Uruk-korban (Kr. e. 4. évezred második fele) is. Az első két korszakot a nagyszámú pattintott kova és obszidián eszköz (KIRÁLY, 2017) és a festett kerámia jellemezte, míg az utóbbit kőedények töredékei és a jellegzetes vágott peremü edény (bevelled-rim bowl). Még kevés információnk van a későbbi megtelepedésekről, de az utolsó évadban, az északi szelvényben (1A felület), közel 8 méteres mélységben úgynevezett Ninive 5-kori és kora bronzkori (Kr. e. 3. évezred eleje és első fele) kerámia is előkerült. ${ }^{3}$ Ma még kevésbé világos, hogy mit történt a kora bronzkor és a Kr. e. 9. századi asszír foglalás között. Úgy tünik, hogy legfeljebb kisebb majorsági központok állhattak itt a középső és a késő bronzkor-

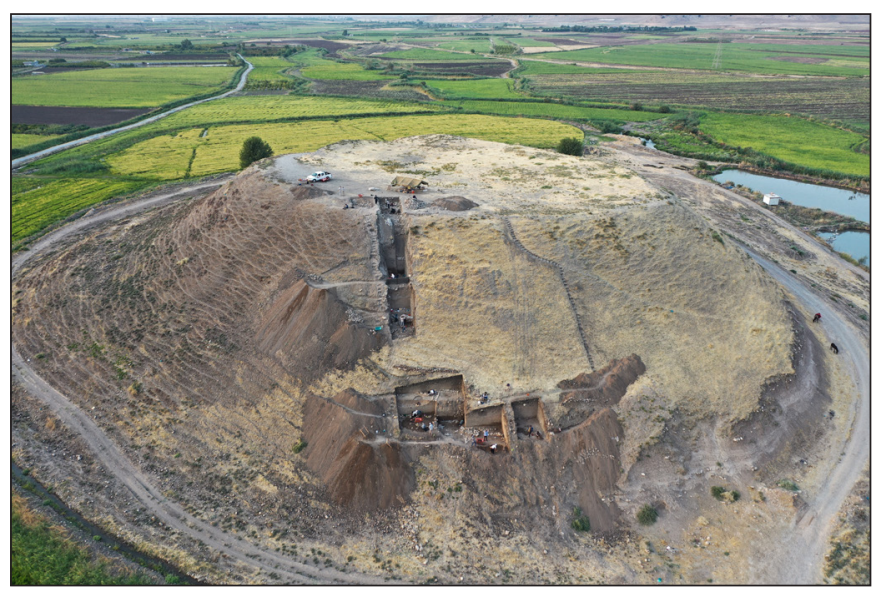

3. kép. A domb drón felvétele északi irányból a 2019-es ásatási évadban. Legfelül az 1-es felület (újkori és alatta

hellénisztikus-pártus erödítmény), közvetlenül alatta az 1 A felület két felszine (az újkori, a hellénisztikus-pártus

és az újasszír kori eröditmény omladéka és az utóbbi teraszfeltöltése), alul a 4. felszín hellénisztikus-pártus kori rétegei. A legalul 2018-ban megnyitott 4 A felszín a visszatemetés miatt nem látható. A háttérben a megmüvelt termékeny földek és halastavak, közöttük öntözöcsatornák.

\footnotetext{
A fémkeresős kutatást Sándor Lajos végezte 2016-ban.

3 Az 1A felület munkálatait Dezső Tamás és Fülöp Kristóf irányították.
} 
Kalla Gábor - Dezsö Tamás • Magyar ásatások iraki Kurdisztán hegyei között

ban. Viszont az utolsó évadra 24 méter hosszúra nyúlt 1A felszínen helyenként 8 méter mélységben feltárt rétegsor megvilágította a tell mai formájának képződési folyamatát is (3. kép). Kiderült, hogy az asszírok az eredetileg valószínúleg kb. 22-24 méter magas őskori eredetủ kúpos dombon az eredetinél sokkal szélesebb teraszt alakítottak ki, hogy egy nagy kiterjedésü erödítményt emeljenek a tetején. Mindehhez több mint 4 méter vastag feltöltést hordtak fel a domb felső részére. Az eddig még nem kiásott citadella alatti területet rézsűvel (glacis) erősítették meg. A domb alsóbb részeit teraszosan építették be.

Az asszír település felhagyása után legalább háromszáz évvel a hellénisztikus-pártus korban valószínüleg a régi romok felett újabb erődítményt emeltek, a legutolsó építési fázisának 4 méter széles maradványai az utolsó évadban kerültek elő az 1. felszínen. Felette az iszlám kor folyamatosan megújított erődítményfalai álltak.

Szinte valamennyi időszakra ugyanaz a falazási mód volt jellemző, alapozásként és gyakran lábazatként is agyaggal összekötött köveket használtak, erre húzták fel a napon szárított agyagtéglából emelt falakat. (Egyetlen kivételt az iszlám korú vár habarcsba rakott külső fala jelentette). Időszakonként csak a felhasznált kövek mérete tért el egymástól, magukat a falakat eddig minden megfigyelt esetben elmosta a rendkívül erős téli és tavaszi esőzés, melynek hatásai az ásatáson is érzékelhetőek voltak.

\section{AZ ISZLÁM KOR EMLÉKEI}

2016-ban a tell felső teraszán megnyitott 1. felületen két szelvényben kerültek elő a 18-19. századi vár maradványai, a félkör alakú bástyákkal megerösített külső fal és belül gazdasági szárnyak és udvar (4. kép). ${ }^{4}$ Körítőfalként egy korábbi, viszonylag gyenge, $80-90 \mathrm{~cm}$ vastag habarcsba rakott falat használtak és ezt köpenyezéssel erősítették meg. Bár a várat az alapokig lerombolták, ennek a falnak a kövei a terasz szélén ma is sok helyen láthatóak, és a déli oldalon egy kapuépítmény körvonala is megfigyelhető. Belül a kő alapozású agyagtégla falakból épült gazdasági épületeket folyamatosan megújították, itt legalább tíz építési fázis volt megfogható. Az udvarban a felső nyílású kerek, úgynevezett tennur(tandur) kemencék sora került elö, ezekben készül-

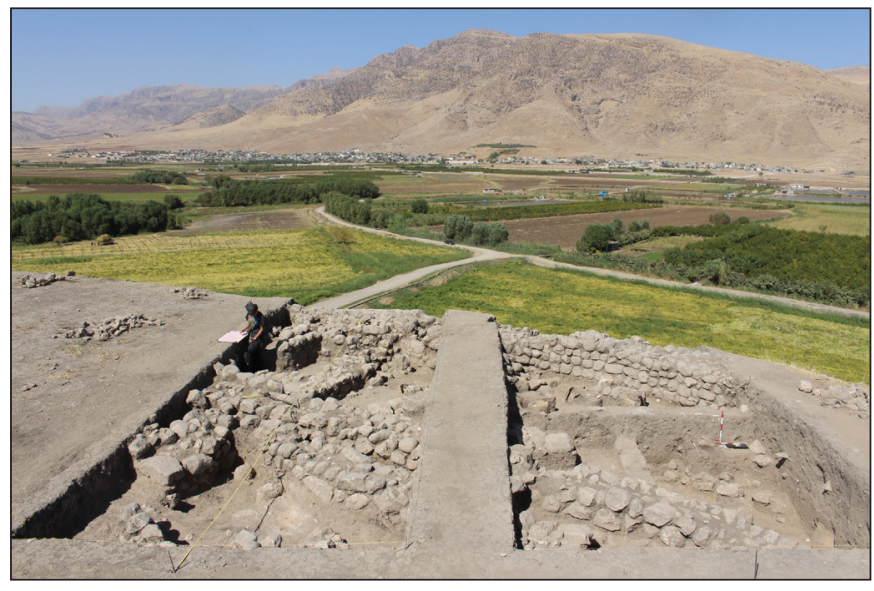

4. kép. A 18-19. századi kurd vár maradványai a felsö terasz felöl (1. felület). A tell körül rizsföldek és gránátalma kertek, a háttérben pedig Szarucsáva falu és a Makuk-hegy láthatók. tek a helyőrség lepénykenyerei. Érdekes, szokatlan részletet jelentett, hogy egyes kemencék belsejébe jeleket véstek, talán egy ősi zoroasztriánus hagyománynak megfelelően. A legfontosabb keltező leleteket a nagy számban előkerült pipavégek és a Szafávida-kori pénzek jelentették. A vár talán a törököktől ideiglenesen függetlenedett Szoráni Emirátus egyik erösségeként müködött, melyet az oszmán hatalom 1835-ben vert le. Ezzel lehet összefüggésben a falak módszeres lerombolása, és egy, erre az időszakra tehető ostrom jellegzetes leletcsoportját jelenthették azok az ólom puskagolyók, melyek a várban és a külső részüt betemető omladékban is megtalálhatóak voltak (DEzső Mordovin 2016; MaseK - Mordovin, 2016a; 2016b).

Elképzelhető, hogy nagyjából ugyanehhez az időszakhoz tartozhatott az alsóváros déli oldalán, az 5. felületen 2017-ben kutatott kő alapozású, négyzetes tornyokkal megerősített kapuépítmény is, bár ennek falazási módja eltért a várétól. Itt az 1,30 méter átmérőjü falnak csak a külső borítása készült kőből, a belső részét vert agyagból emelték. A kevert leletanyag miatt nem egyértelmü, hogy az iszlám korra, vagy a hellénisztikus-pártus időszakra tehető a kapu, illetve a hozzá tartozó városfal (Dezső et al., 2017, pp.

\footnotetext{
4 Az 1. felület munkálatait 2016-ban Mordovin Maxim és Masek Zsófia, majd 2019-ben Németh Fruzsina és Németh Veronika irányították.
} 
Kalla Gábor - Dezsö Tamás • Magyar ásatások iraki Kurdisztán hegyei között

384-390). ${ }^{5}$ A fémkeresős kutatások és az alsó városban a 3. felületen 2016-ban feltárt 18-19. századi lakóépület részlete kemencével és benne egy díszes bronz csészével inkább az előbbi lehetőséget valószínüsítik (DEzső et al., 2016, p. 240), ${ }^{6}$ ugyanis ez a lakónegyed valószínüleg védelmet igényelt. A falazat típusa miatt az is elképzelhetö, hogy erre a hellénisztikus-pártus városfalra épült később a középkori, de ez utóbbi mára már elpusztult. Sajnos a kettős falgyürü maga nem kutatható, mert a maradványait jelenleg a környező rizsföldek öntözöcsatornájaként használják.

Az iszlám kor másik fontos emlékcsoportját jelentik a temetkezések, melyek a domb keleti oldalának teljes felületét beborítják, de valamivel szórványosabban az északi oldalon is megfigyelhetőek.

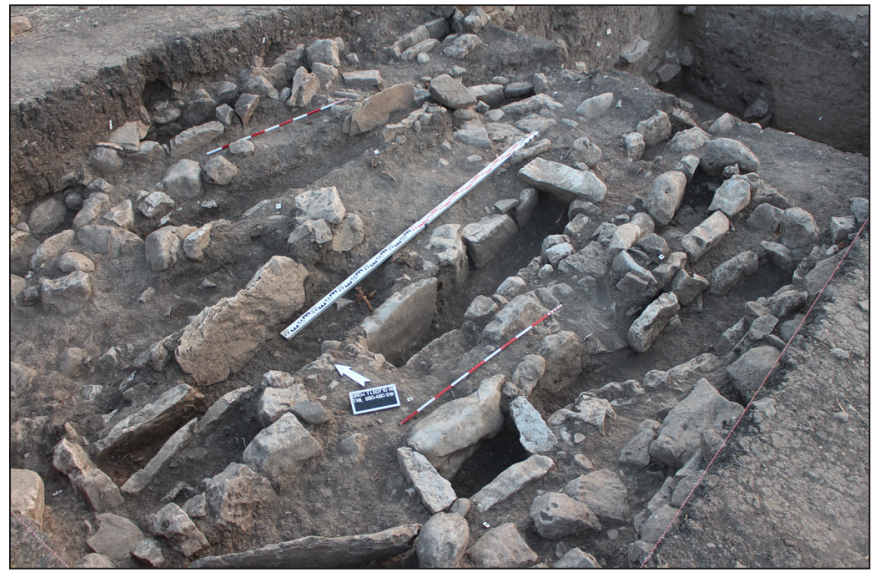

5. kép. 16. századi köládás sírok a domb keleti oldalán közvetlenül a felszín alatt (2. felület). Ezek fölött még számos csecsemösir feküdt. Jól látható, hogy a korábbi korszakok falaiból kinyert kövek formája rendkívül változatos.

A domb keleti oldalának középső teraszán nyitott 2. felület két szelvényében 2016-ban és 2018-ban nagyjából $40 \mathrm{~m}^{2}$ felületen közel 50, sürün egymás mellé elhelyezett sír került elő (5. kép), ${ }^{7}$ továbbiakat tártunk fel az 2019-ben az 1A, a 4B és a 4D szelvényekben. 2016-ban a 2. felületen jól megfigyelhető volt, hogy a temetőnek két időszaka volt, egy szórványosabban használt korábbi és egy sürübb későbbi. A korábbi temetkezések esetében a jobb oldalra fektetett halottakat először egy sekély, keskeny gödörbe helyezték el, majd hosszúkás kövek sorával fedték le azokat, míg a későbbieknél először egy szélesebb és mélyebb gödröt ástak, és a hátukra helyezett testeket élükre állított kisebb lapos kövekkel rakták körbe, és nagyobb lapos kövekkel fedték le a konstrukciót. Ez utóbbi esetben tehát egyfajta szabálytalan formájú kőláda alakult ki. Mindkét időszakban a testet kelet-nyugati irányba fektették, az arcot pedig délre, Mekka felé fordították. A megmunkálás nélküli, tört és hordalékköveket korábbi építményekböl gyüjtötték össze, a különböző méreteket és formákat pragmatikusan használták fel, így sokszor szabálytalan megoldások keletkeztek. Mellékletük sohasem volt, és nagy arányban voltak köztük az egész fiatal gyerekek, csecsemők és magzatok temetkezései, melyeket általában felnőttek sírjai között szorosan, vagy azok felett helyeztek el. Ez utóbbi esetben természetesen nem volt sírgödör (KALLA - SzABó, 2016). A csontminták radiokarbon kormeghatározása alapján a korábbi időszak temetkezései a 12. század második felére, míg a későbbieké pedig nagyjából a 16. század körülre tehetőek. ${ }^{8}$ Ez azt jelenti, hogy a temető nem ahhoz a késő iszlám településhez tartozott, amit eddig régészetileg kutattunk.

\section{HELLÉNISZTIKUS-PÁRTUS IDŐSZAK EMLÉKEI}

A Nagy Sándor keleti foglalása (Kr. e. 333-323) utáni időszakban a mediterrán hatások igen erősen érezhetőek voltak a Zagrosz-hegyvidéken is, és ezek nem szüntek meg a Pártus Birodalom (Kr. e. 3 - Kr. u. 3. század) megalakulása után sem. Mivel a lokális kerámiakészítési tradíciók fennmaradtak, és más, pontosabb keltező emlék egyelőre nem áll rendelkezésre, a két időszakot csak egyben tudjuk kezelni. A kezdeti időszak legfontosabb keltező értékü leletét két makedón ezüst érme, például a 2. felületen talált, Kr. e. 310 és 301 között Lampszakoszban vert ezüst tetradrakhma jelenti (6. kép; DEzső et al., 2016, p. 239). A kerámia mellett a kormeghatározás egy másik biztos kiindulópontját az ebben a térségben csak a hellénisztikuspártus időszakban használt mediterrán tetőfedési forma, a lapos peremes (tegula) és a közöttük maradt helyet lezáró ívelt tetőcserép (imbrex) megjelenése jelenti. Ezek darabjait nagy számban találtuk meg.

\footnotetext{
Az 5. felület munkálatait 2017-ben Ardalan Khwsnaw és Aram Ali Hama Amin irányította.

A 3. felületen 2016-ban a munkákat Szabó Nóra irányította.

A 2. felület ásatását Kalla Gábor irányította, 2016-ban Szabó Nóra, 2018-ban pedig Németh Veronika segítették a munkálatokat.

Az MTA ATOMKI mérési eredményeinek kalibrálását Siklósi Zsuzsannának köszönjük.
} 
Kalla Gábor - Dezsö Tamás • Magyar ásatások iraki Kurdisztán hegyei között

Az ásatás során több különböző felszínen is kimutatható volt, hogy a korszak kezdetének építményeit közvetlenül az újasszír kor maradványaira emelték, sokszor a korábbi falak vonalát is követve. 2017-ben a 4. felszínen került elő egy 1 méter széles kelet-nyugati fal egy bejárattal, melynek folytatását 2019-ben keletre a 4B, és nyugatra a 4C szelvényekben is megtaláltuk (7. kép). Mivel az épület nagy része a domb belsejében folytatódik, ma még nem állapítható meg az épület jellege, de valószínűleg egy nagyobb lakóépületről van szó. Ez az épület közvetlenül (kb. 30 cm-el) egy gazdag újasszír kori lakóház felett állt, feltöltésébe nagy számban keveredettek bele a korábbi szint kiemelkedő fontosságú emlékei (ld. később).

Ugyanígy egy újasszír épület romjain húztak fel egy reprezentatív, nagyméretü kőlapokkal borított udvarral rendelkező épületet, melynek maradványait 2018-ban, a 2. felszínen tártuk fel. Itt a kőlapok kiegyensúlyozáshoz is a helyen talált újasszír kori kerámiát használták fel (KALlA - Dezső, 2019).

A korszakba sorolható széles kőfal 2019-ben az 1A felszínen is elökerült. Az ilyen típusú falak értelmezésénél mindenhol ugyanabba a problémába ütköztünk. A legalább 3 méteres mélység miatt csak kisebb felületen tudtuk feltárni azokat, valamint az erózió miatt általában hiányoznak a padlószintek, így nehezen állapítható meg, hogy milyen konstrukcióról van szó: teraszok támfalairól vagy épületek falairól. A kettő össze is függhet, mivel az újasszír kori terepviszonyokat követve a domb oldalát ekkor is teraszosan építették be, így a lakóházak teraszainak támfalakra volt szükségük

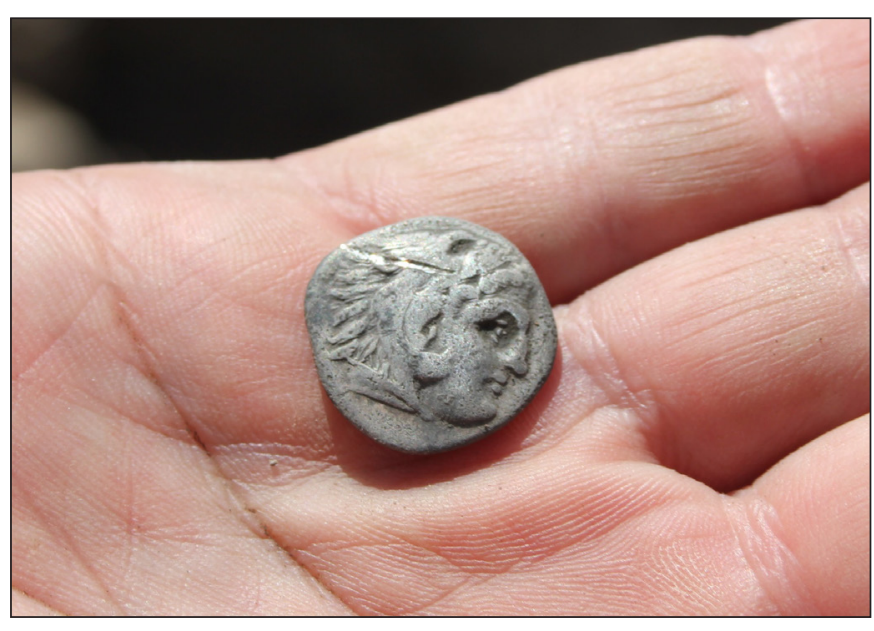

6. kép. A 2. felületen 2016-ban elökerült makedón ezüst tetradrakhma a megtalálásakor. Kr. e. 310 és 301 között verték Lampszakoszban.

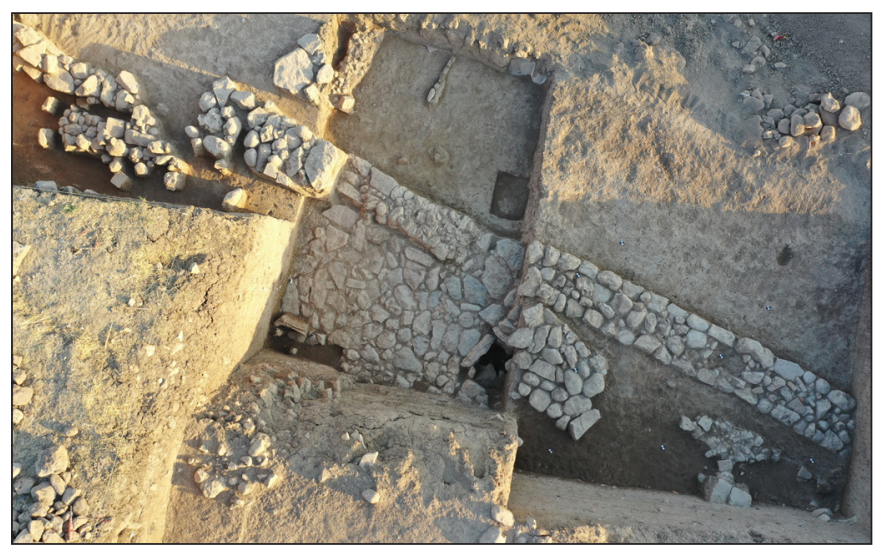

7. kép. A 4-es, a 4B és a 4C felületek drón képe a 2019-es évad végén. Középen a 2018-ban feltárt és részben újra megnyitott újasszir kori ház a kövezett udvarral, jobbra és balra, a maradványaira közvetlenül ráépittett hellénisztikuspártus kori épület két építési fázisának falai.

A legkorábbi hellénisztikus-pártus szint fölött a keleti oldalon a 2. és az északi oldalon a 4. felületen (4B és $4 \mathrm{C}$ szelvényekben ${ }^{9}$ ) is megfigyelhető volt egy legalább két méter vastag szint, melyben ipari tevékenység nyomait, jórészt kemencék alapozását, illetve szétrombolt égetőkemencék falának töredékeit találtuk. ${ }^{10}$ A feltöltés tele volt égett anyagdarabokkal, illetve faszénnel. Emellett sok vas- és üvegsalak is előkerült. 2019-ben a 4B felületen sikerült egy, nagyjából a rostély szintjéig megmaradt égetőkemencét részben feltárni, melynek tủzkamráját szinte teljesen bevonta egy üvegréteg (8. kép). Hasonló két kemence alsó részét a 4C felületen is kiástuk. Ezekben talán edények mázazását végezhették, de sajnos rontott darabok még nem kerültek elő. Más kemencéket vasmegmunkáláshoz használhattak. A folyamatos szintemelkedést az elhasznált kemencék gyakori lerombolása, a terület elegyengetése és újak emelése okozhatta. Mindez arra utal, hogy a település egy része viszonylag hosszabb időszakban ipari zónaként működött.

A harmadik hellénisztikus-pártus időszak lakóházainak maradványait 2016-ban és 2017-ben a 2. felületen (DEzső et al., 2016, pp. 371-377) és 2019-ben a 4B felületein tártuk fel, de egyik esetben sem tudtunk padlót megfigyelni. A 4B felszín területén a ház felhagyása után egy zsugorított temetkezést helyeztek el (8. kép), melyek melléklete egy vas kés, egy vas nyílhegy, és egy csontból készült íj markolatdísz volt.

9 2019-ben a 4B felületen a munkálatokat Kalla Gábor, a 4C felületen Király Attila, a 4D felületen Szabó Nóra irányította.

10 A 2017-es évad megfigyeléseit a 2. felületről lásd DEzsö et al., 2017, pp. 371-377. 
Kalla Gábor - Dezsö Tamás • Magyar ásatások iraki Kurdisztán hegyei között

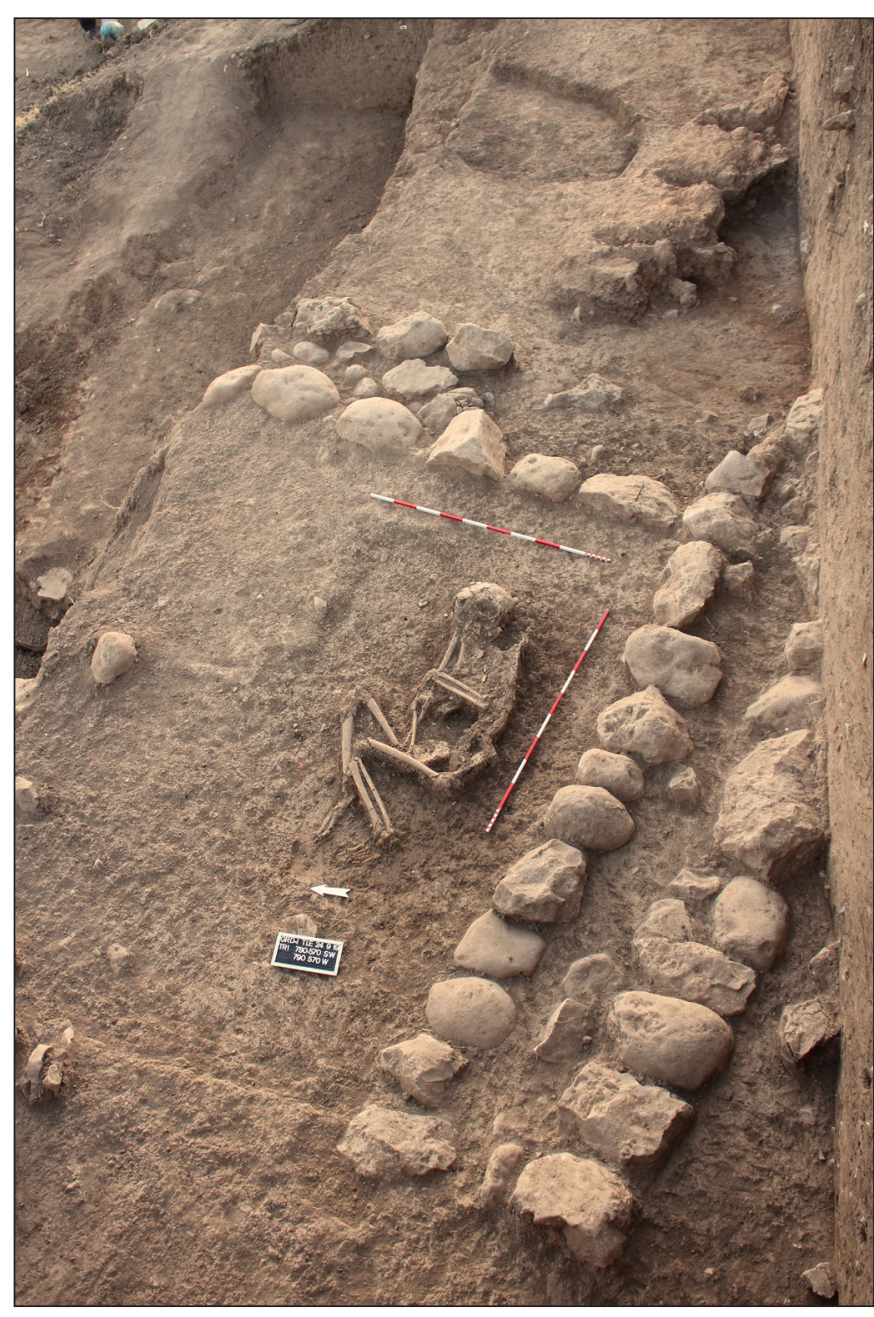

8. kép. A legkésöbbi hellénisztikus-pártus kori ház a 4B felületen. Elötérben a ház elhagyása utáni, de még ebbe a korszakba tartozó temetkezés. A háttérben egy megelözö réteghez tarozó ipari kemence felsö része. Valószínüleg edények mázazására használták.

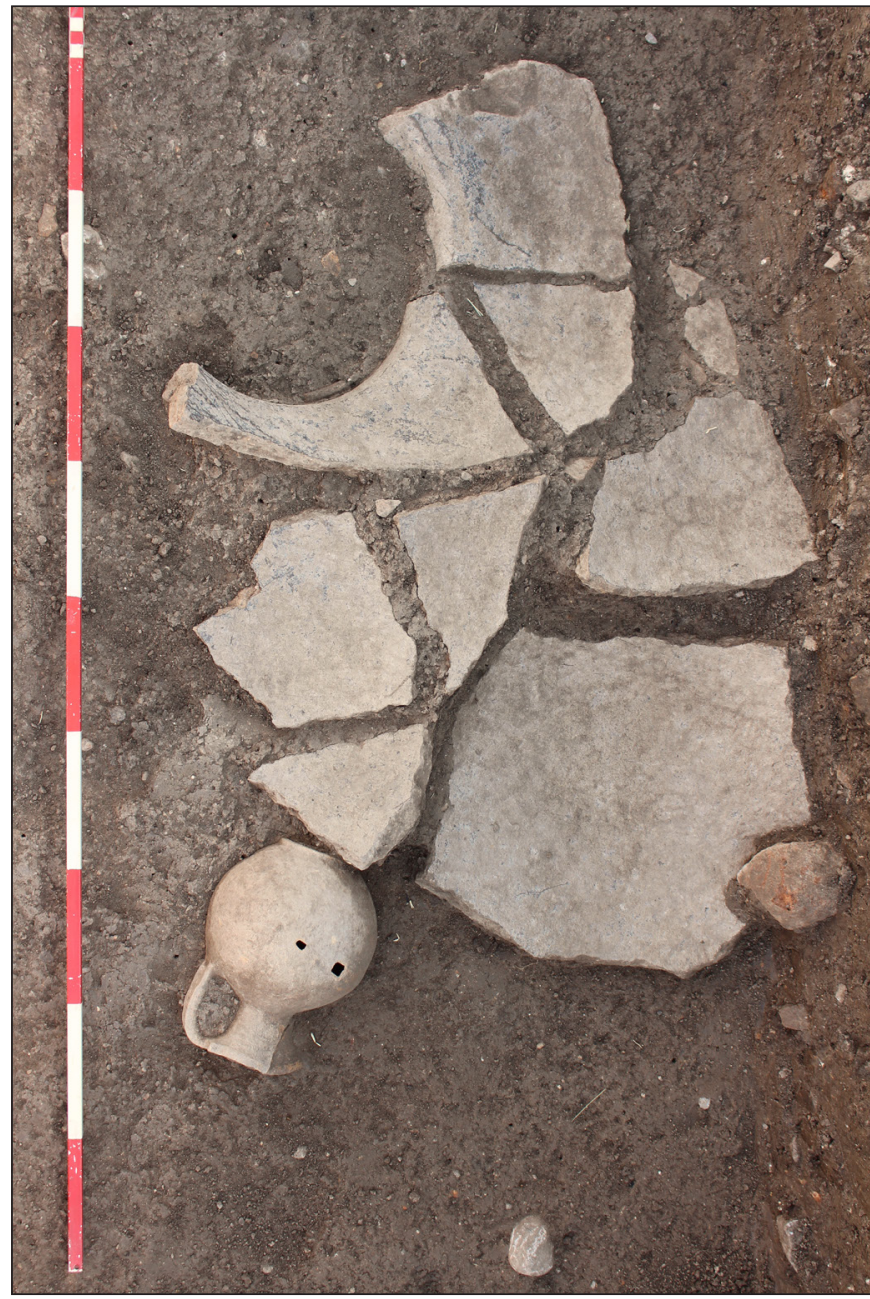

9. kép. Hellénisztikus-pártus kori edénydepó egy ép boroskancsóval (oinokhoé) és egy nagyméretü tárolóedény (pithos) töredékeivel (4B felület).

Efölött több korabeli edénydepót is találtunk, amely hol egyetlen, hol pedig több edényből állt. Ezek jelentősége, hogy az első ép, vagy teljesen rekonstruálható edényeket jelentették ebből a korból (9. kép).

A felső platón 2019-ben újra megnyitott 1 . felületen az iszlám rétegek alatt két méter mélységben elértük a hellénisztikus-pártus kori erődítményfal szintjét, melynek a domb északi rézsűjét beborító kőtörmelékei az 1A felszínen már korábban előkerültek (Dezső et al., 2017, pp. 364-369). Maga a masszív fal 4 méter széles, és viszonylag nagyméretü agyagba rakott kövekből készült. Az eddigi tapasztalatok alapján az újasszír kori citadella falát a következő évadban valahol ez alatt kell keresnünk; 2018-ban ettől északra, az 1A szelvényben, a domboldal felső részén 4 méter mélységben egy korabeli masszív teraszfalat már kiástunk.

\section{AZ ÚJASSZÍR KOR EMLÉKEI}

Az újasszír kori emlékeknek a kutatási program során célul kitüzött feltérképezése eleinte nagy nehézségekbe ütközött. Kiderült, hogy a domb felső részein a későbbi időszakok vastag törmelékei borítják a korabeli szinteket, az áttörést jelentő 2018-as kampány során viszont egyszerre négy felületen is előkerültek a korabeli maradványok (KALLA - DEzső, 2019). Ekkor vált világossá, hogy legegyszerübben az északi oldalon, a középső terasz alatt, a tíz méternél alacsonyabb szinteken lehet elérni az újasszír rétegeket.

Az északi oldalon úgy jelöltük ki a 4. és a 4A felületet, hogy az 1A szelvénnyel együtt később a domb egy teljes metszetét megkapjuk, legalábbis 3-4 méteres mélységig. 
Kalla Gábor - Dezsö Tamás • Magyar ásatások iraki Kurdisztán hegyei között

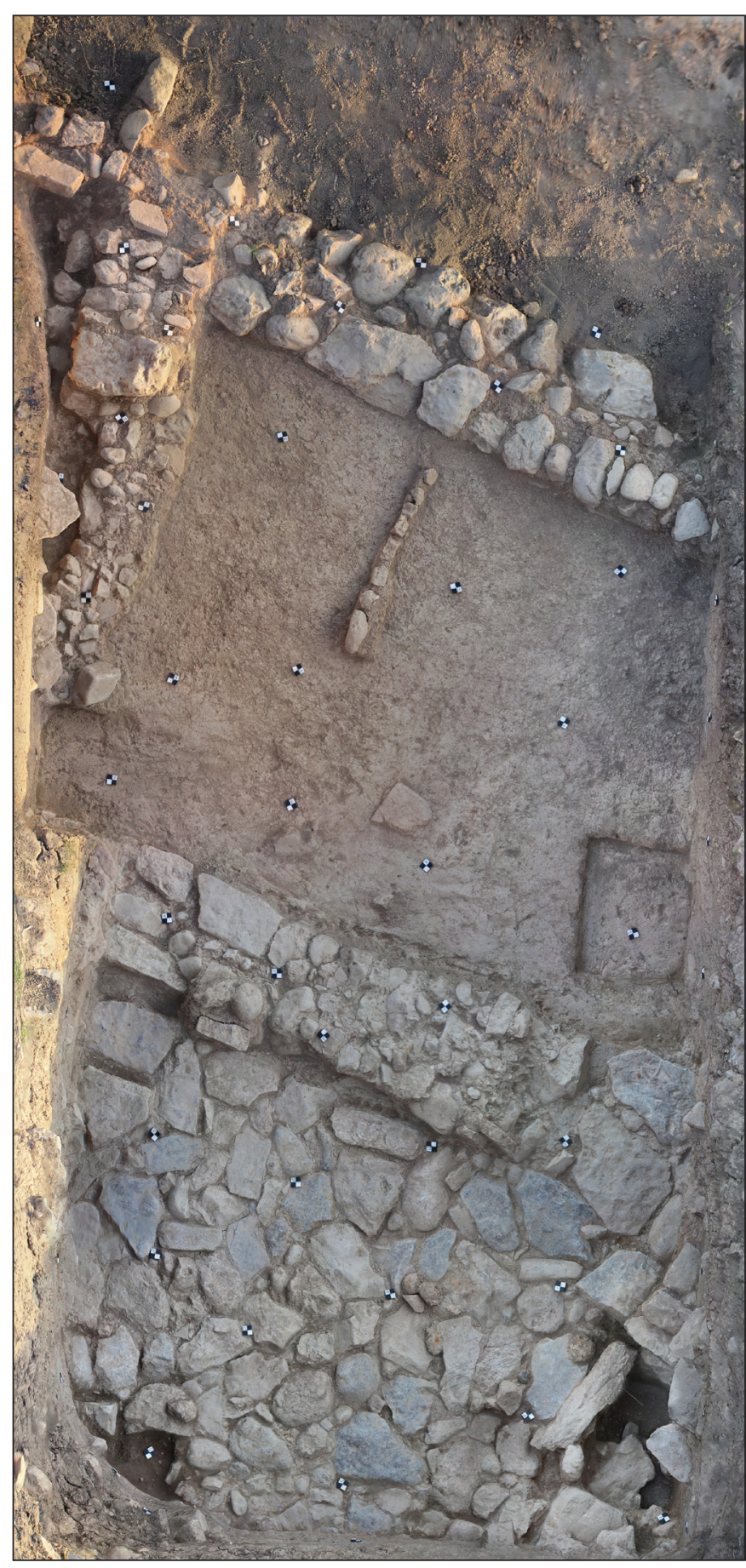

10. kép. A 4. felszín 2018-ban feltárt újasszír kori lakóházrészlete a gondosan kövezett udvarral. Felül a sörfözésre is használt gazdasági helyiség. A sörfözö edények a helyiség közepén látható alacsony fal mellett álltak sorban. (Az orthofotó Bödöcs András munkája).

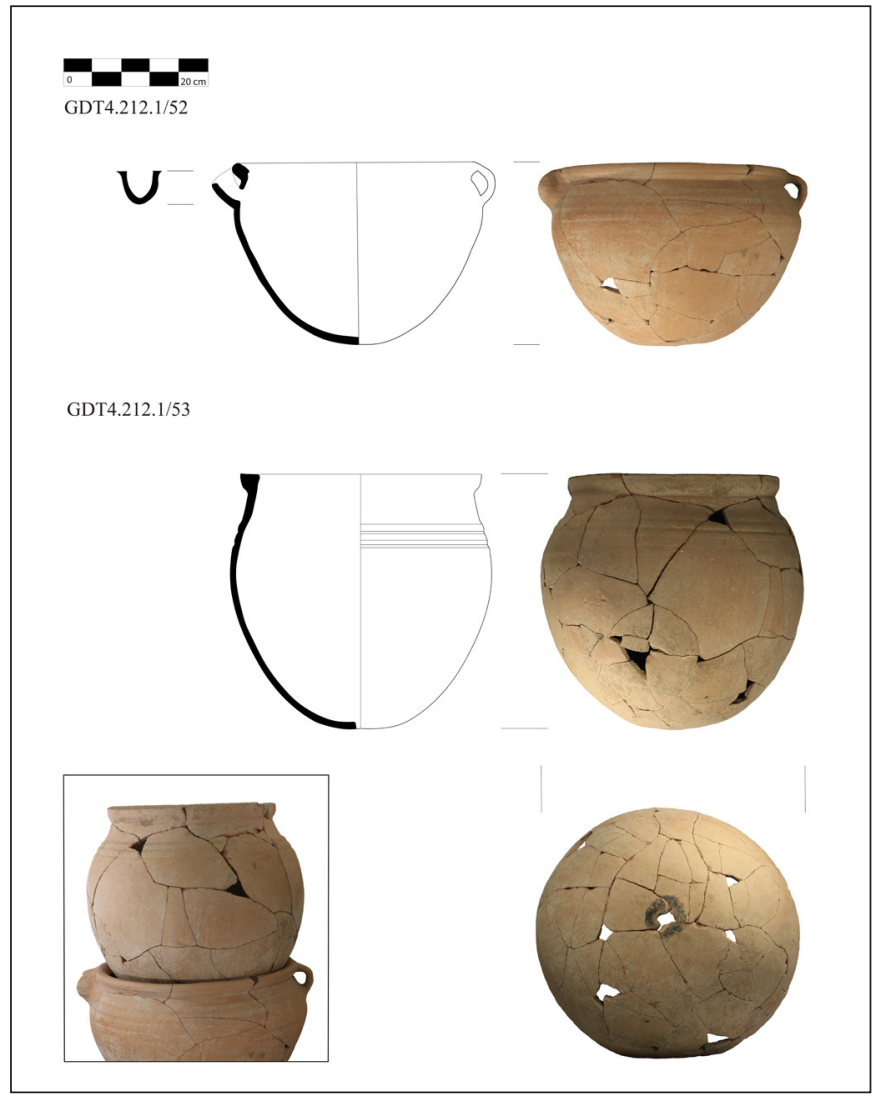

11. kép. A 4. felszín újasszír korából feltárt sörfözö edények. Az alul átlyukasztott és a nyílás körül bitumennel kikent edényt a sör erjesztése során a kiöntöcsöves darabokra helyezték, ahogy a képen is látható.

A 4. felületen közvetlenül az egy évvel korábban kiásott hellénisztikus-pártus fal alatt egy újasszír kori lakóház maradványai bukkantak elő (10. kép). ${ }^{11}$ Bár az arányai miatt legalább 150-200 m²-re, vagy még nagyobbra becsülhetö épületböl eddig csak nagyjából $35 \mathrm{~m}^{2}$-t, két helyiséget, egy udvar egy részét és egy gazdasági helyiséget tártunk fel, rögtön valószínüvé vált, hogy egy jelentős asszír tisztviselői háztartásról van szó. Erre utalt többek között az udvar kő borítása, ami viszonylag ritka az Asszír Birodalom területén, és csak a fontosabb lakóházakra jellemző (Miglus 1999, pp. 131-175, Taf. 64-85). Ebben az esetben láthatóan törekedtek a látványos polikróm megjelenésre, gondosan válogatták ki és helyezték el a fehér, szürke, vörös és kék köveket.

Az udvarról két ajtó vezetett egy döngölt padlós gazdasági helységbe, amit konyhaként és sörfőző mühelyként használtak. Itt egy tennur-kemence maradványai mellett három nagyméretü, nagyjából 18 literes, nyitott szájú, vékony falú edény került elö, kettő közülük perem alatti kiöntőcsővel rendelkezett, a harmadik alját pedig kilyukasztották és a nyílást körben bitumennel kenték ki (11. kép). Mindhármat a helyiség közepén, egy sorban, egy észak-déli irányba futó alacsony fal mellett találtuk, gömbös aljuk miatt

11 A 4. felszín munkálatait Király Attila irányította. 


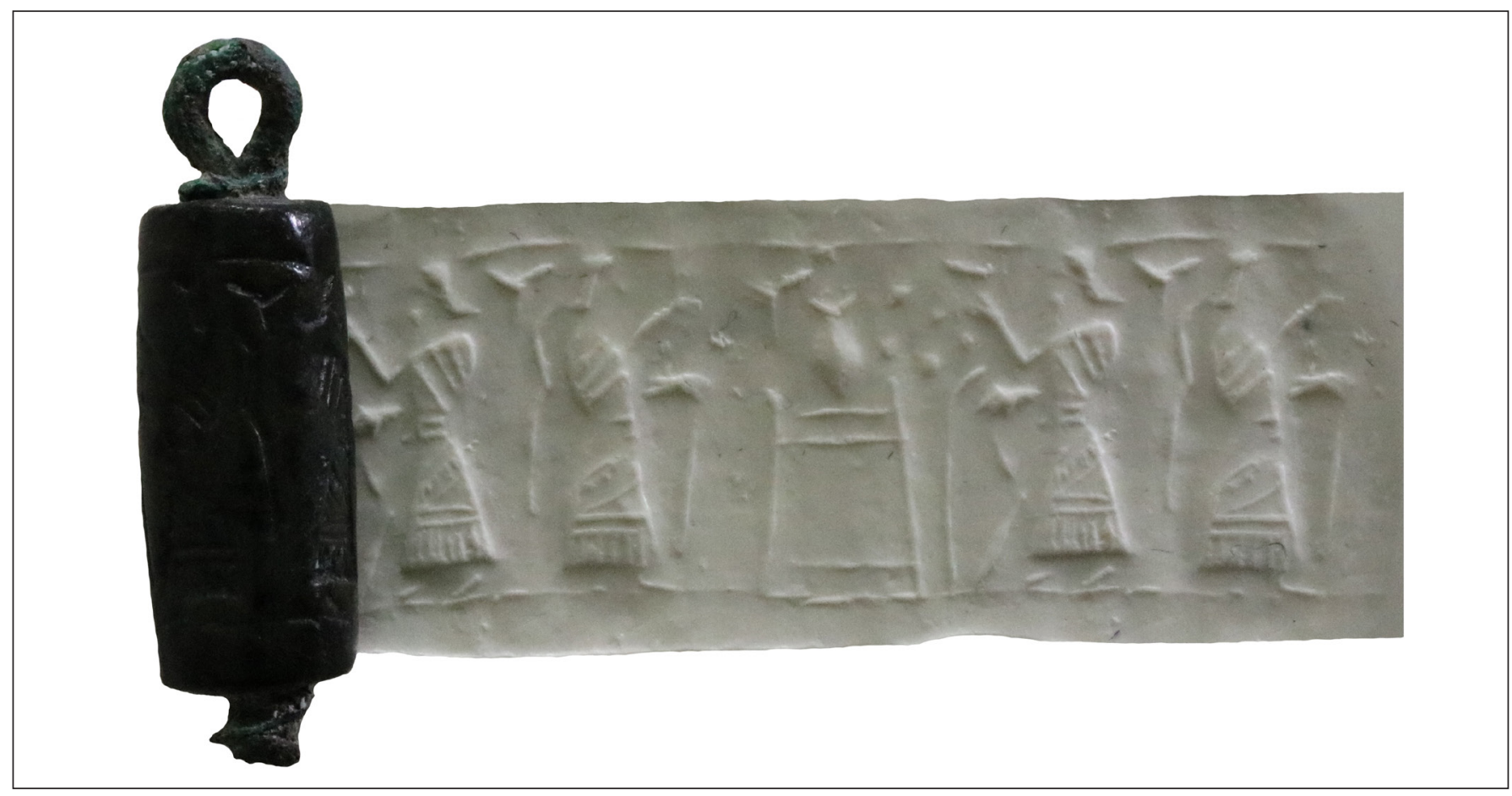

12. kép. A 2019-ben a 4B felületen elökerült újasszír kori pecséthenger. A szerpentinböl készült darabon egy rituális jelenet látható a királlyal és egy magas rangú tisztviselővel. Ez az elsö asszír pecséthenger, ami a régióban előkerült.

kövekkel, illetve kerámiatöredékkel rögzítették öket. Eddig az újasszír korban még nem azonosított a kutatás sörfőző edényeket, de korábbi időszakok (középső és késő bronzkor) párhuzamai alapján egyértelmü, hogy a lyukkal ellátott edény szolgált a sör erjesztésére; ezt a kiöntőcsöves edényekre helyezték rá, ahova egy alul elhelyezett textilen keresztül csuroghatott át a sör. A helyiségben ezen kívül számos, gabonaőrlésre szolgáló eszköz, például mozsártörö és más edények is előkerültek.

A ház omladékában már 2018-ban is több olyan leletet találtunk, amely elit fogyasztásra utalt, így például az ekkoriban még igen drága mázas kerámia töredékeit, de a legérdekesebb darabok a következő évadban bukkantak elő.

2019-ben már három különböző szelvényben (4B, 4C, 4D; 6. kép), nagyobb felületen próbáltuk vizsgálni ezt a lakóházat. Bár a későbbi korok fontos emlékei miatt végül csak megközelítettük az újasszír szintet, idő hiányában már nem tártuk fel, mégis ebből a szempontból is igen fontos eredményeket hoztak ezek a felületek.

A későbbi rétegekbe ugyanis nagy számban kerültek be az asszír lakóházból származó különleges tárgyak, kvarckerámiából (fajansz) készült egyiptomi skarabeusz hieroglif felirattal, két szintén kvarckerámia pecsétnyomó (skaraboid), és úgynevezett egyiptomi kék gyöngyök és függők, mind távoli importok Egyiptomból és Föníciából. Emellett Irán keleti részéből származó karneolból készült gyöngyöket is találtunk. Az asszír magterülettel való kapcsolatokat a mázas kerámia mellett a rendkívül jól égetett, vékony falú edények, az úgynevezett palotaáru (Palace Ware) töredékei jelezték.

Az utolsó évad egyik legfontosabb lelete, ami megerősítette, hogy valóban egy jelentős asszír tisztviselői háztartásról van szó, egy szerpentinből készült pecséthenger volt (12. kép). A bronz fogóval ellátott, 2,3 cm hosszú, 1,0 cm széles tárgy felületén az asszír uralkodó jelenik meg, egy udvari tisztviselő társaságában, egy rituális jelenetben. A valószínűleg hosszú ideig használt, kopott felületű henger az ún. lineáris stílusban, erősen leegyszerüsített stíluseszközökkel készült. A jelenetet a nagy számban ismert párhuzamok révén érthetjük meg: ${ }^{12}$ az uralkodó jobb kezével egy csészét emel fel, a baljában a katonai hatalmát jelképező íjat tart. A másik oldalon egy tisztviselö bal kezével egy zászlószerü legyezőt emel, jobbjával egy jogart tart, ami kiemelt státuszát jelzi, vállán egy kendő. Közöttük egy áldozati asztal, edénnyel. Ennek

12 Lásd például Collon, 2001, pp. 64-70, Plate IX-X. 
Kalla Gábor - Dezsö Tamás • Magyar ásatások iraki Kurdisztán hegyei között

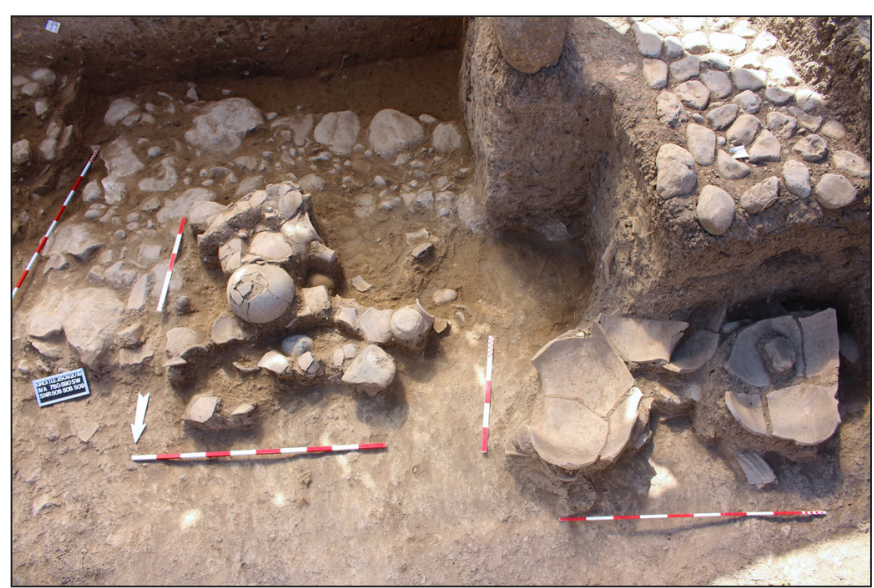

13. kép. A 4A felszinen 2018-ban feltárt újasszír ház egy helyisége halmokba rakott edényekkel és köeszközökkel. Felette egy következö épitési szint házának kövel boritott udvara.

a királyi hatalmat megerősítő rituálénak a jelenete palotadombormüveken is felbukkan, a pecséthenger müfaja éppen ezt a hatalmi szimbolikát terjesztette el birodalom-szerte, ahogy ezt a párhuzamos darabok szóródása is jelzi. Bár egyértelmü bizonyítékunk nincs, mégis nagy valószínűséggel állíthatjuk, hogy ezt a típust az Asszír Birodalom középszintü tisztviselöi használhatták.

A 2018-ban, a domb északi lejtőjének alján nyitott 4A szelvényben szintén egy újasszír kori lakóház maradványai kerültek elő, helyenként közvetlenül a felszín alatt. ${ }^{13}$ A kevert leletanyag miatt ma még nem tudjuk biztonsággal megmondani, hogy a közvetlenül felette megtalált kövezett udvar egy újasszír kori megújításhoz, vagy a hellénisztikuspártus időszakhoz tartozik. Az udvar alatt, kis felületen is nagy mennyiségü leletanyag került elö, két csoportban. Ezekben szinte teljesen ép finomkerámiát, főzőedényt, tárolóedényeket, durván megformált korsókat és csészéket munkakövekkel összekeveredve találtunk (13. kép). Mintha szándékosan rakták volna őket halmokba. A kerámiaanyag nagy része helyi, vaskori tradíciókat tükröz, a finomkerámia viszont asszír jellegü. A kőanyag, a mozsártörők és az őrlőkövek is archaikus jellegzetességűek. Az elit tárgyak és a használati kerámia kettőssége szépen mutatja az asszír foglalás utáni összeolvadás folyamatát.

Az asszír lakóházakat a meredek domboldalban kialakított teraszokon helyezték el, például a 4-es és a 4A szelvények nagyjából egykorú épületei 10 méter távolságban 9 méteres szintkülönbséget mutattak.

A domb keleti oldalán, a 2. felületen 2018-ban szintén előkerült egy újasszír kori épület maradványa (KALlA - Dezső, 2019). Az 1,20-1,30 m vastag falak kőlapozásában előkerültek függőlegesen elhelyezett gerendák nyomai, melyeket az agyagtégla felépítményben vízszintesen rakott gerendák egészíthettek ki, ezeket nem feltétlenül rögzítették egymáshoz. Ez a fagerendás falmegerősítés, ami földrengés esetére kellő rugalmasságot biztosított, jól ismert a szíriaianatóliai régióban (NAUMANN, 1971, pp. 86-108), melyhez ez a vidék kulturálisan tartozott. A falban egy építési áldozat maradványait találtuk meg, egy nagyobb kőtömb mélyedésében, hamus közegben egy kis kézzel formált edény feküdt, melyben valamilyen ételt melegíthettek egy rituálé keretében. A fal méretei egy nagyobb épületre, talán egy kisebb palotára utalnak, de ezt a kis felület miatt még nem tudjuk megerősíteni. Az ebben a rétegben, illetve korábban felette talált leletek, lazúrkő és karneol gyöngyök, valamint egy vas nyelü bronz csengő jelentősebb háztartásra utalnak (14. kép). Ez utóbbi ugyanis egy lószerszám dísze lehetett, a vele talált vörös kő gyönggyel együtt. A ló ekkoriban különlegesen drága portékának számított, és éppen ez volt az egyik olyan régió, amelynek feladata volt, hogy

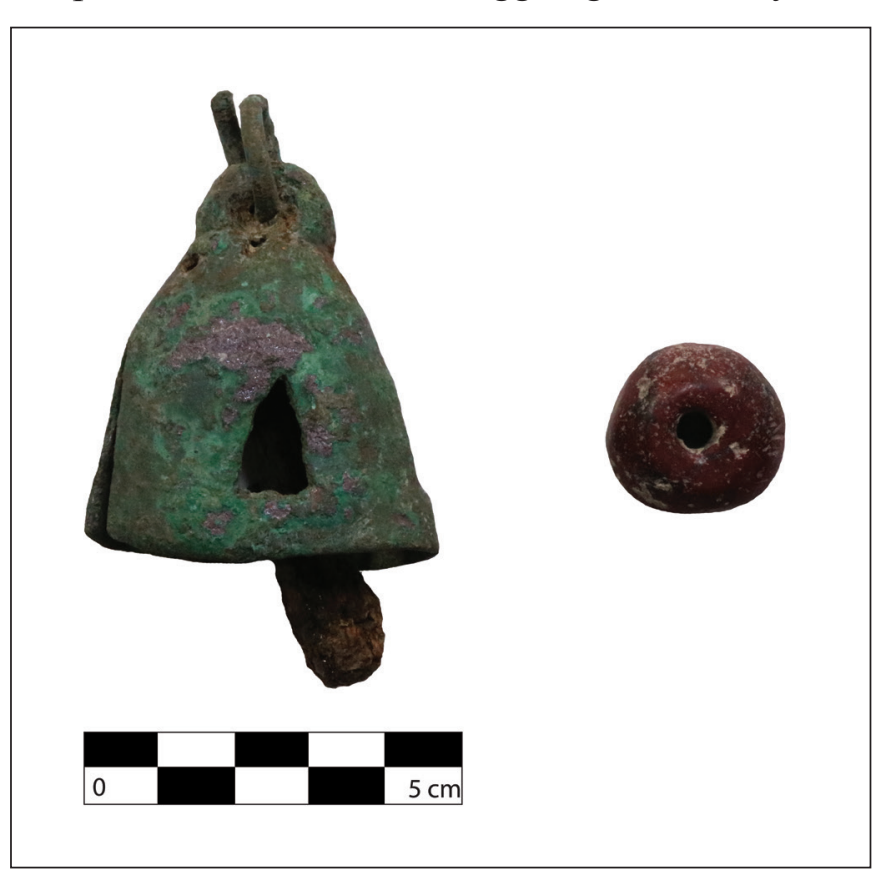

14. kép. Bronz csengö vas nyelvvel és egy fekete erezetes vörös kőgyöngy. A 2. felületen az újasszír kori épület felett egymás mellett elökerült darabok eredetileg lószerszámzat diszei voltak.

13 A 4A felület munkálatait Szabó Nóra irányította. 
Kalla Gábor - Dezsö Tamás • Magyar ásatások iraki Kurdisztán hegyei között

az asszír hadseregnek az iráni hegyvidékről, az akkori világ egyik legfontosabb lótenyésztési és kiképző régiójából utánpótlást szállítson (DEzsö, 2016a, pp. 167-188).

Nem tudjuk, hogy mekkora volt az újasszír kori település teljes kiterjedése, így azt sem, hogy mennyire volt jelentős központ, ugyanis a rizstermelés és a halastavak okozta magas vízszint miatt nem kutatható a külső város korábbi rétege. A szórványos felszíni nyomok alapján a hellénisztikus-pártus korban biztosan használatban volt, néhány fémlelet azonban arra utal, hogy elképzelhető egy korábbi időpont is, de ezt ma még nem tudjuk egyértelmüen bizonyítani.

Az asszír lakóházak gazdag leletanyaga, a jó háztartási együttesek azért tudtak ilyen viszonylagos teljességben fennmaradni, mert egy pusztulási réteg fedte azokat. Keletkezésének időpontját nem tudjuk biztonsággal meghatározni, de a domboldal sok helyén az omladék rétegekben az első évad óta folyamatosan előkerülő, bronzból készült szkíta és asszír típusú vas nyílhegyek egy nagyobb támadásra utalnak, és a 4. felületen az asszír ház omladékában egy emberi test szétesett maradványait is megtaláltuk (DEzsö, 2016b). Bár a háromélủ szkíta típusú nyílhegyeket nem csak ez a népesség használta, tudjuk, hogy Assur-ah-iddina (Kr. e. 680-669) uralkodása alatt az ezzel a területtel szomszédos Mannea felől pusztító szkíta támadás érte a birodalmat (RADNER, 2016, p. 21). Talán ebbe az eseménysorba illik ennek a településnek a pusztulása is, de elképzelhető, hogy a birodalom Kr. e. 614 és 609 közötti bukásával áll összefüggésben. Ha a 4A felszín lakóháza fölötti kövezett udvar asszír kori megújításnak bizonyul, az előbbi a valószínübb, azonban a kérdés megválaszolása mindenképpen további vizsgálatokat igényel.

\section{ÖSSZEFOGLALÁS}

Összességében a négy rövid, egy hónapos évad, melynek ásatási idejét tovább korlátozza az idény végi visszatakarás és a kezdeti újra megnyitás kötelezettsége, jelentős eredményeket hozott. Sikerült tisztázni Grd-i Tle történetének és topográfiájának számos részletét, az iszlám és a hellénisztikus-pártus emlékanyag eddig nem ismert helyi sajátosságait.

Nem csak Grd-i Tle településének asszír igazgatási központ jellege igazolódott, hanem olyan fontos leletegyüttesek is előkerültek, melyek későbbi információkkal kiegészítve teljes háztartások rekonstrukcióját teszik lehetővé, így háztartási szinten vizsgálhatóvá válik az Újasszír Birodalom magterületének és perifériájának viszonya. A gazdasági elemzések részeként úsztatással (flotálás) maglelet mintákat gyüjtöttünk, melyek botanikai feldolgozása rövidesen befejeződik. 2019-ben az ásatást további geológiai és geofizikai vizsgálatok egészítették ki. ${ }^{14} \mathrm{Az}$ eredmények kiértékelése még folyamatban van, de már most látszik, hogy már az ókorban is ez volt a Rania-síkság öntözővízzel legjobban ellátott, és ezért legtermékenyebb területe.

A terepmunka mellett az ásatás bázisán folyamatosan folyt a leletanyag dokumentációja és feldolgozása, amit 2019-töl a restaurálás is kiegészített. ${ }^{15}$

Fontos továbbá kiemelni, hogy Grd-i Tle feltárása a magyar régészet történetének első olyan expedíciója, amelynek célja a mezopotámiai kultúra tanulmányozása.

BIBLIOGRÁFIA

Collon, D., 2001.

Cylinder Seals V. Neo-Assyrian and Neo-Babylonian Periods. Catalogue of the Western Asiatic Seals in the British Museum. London: British Museum.

DEzsö, T., 2016a.

The Assyrian Army II. Recruitment and logistics. Budapest: Eötvös University Press.

\footnotetext{
14 A geológiai vizsgálatokat Viczián István, a geomágneses méréseket Vér Ádám segítségével Surányi Gergely végezte.

15 A leletanyag restaurálását Tóth Eszter végezte, a kerámia feldolgozásában a korábban említett régészek mellett Füzesi András, Abdullah Bakr Othman, Maha Suleiman, és Fuchs Noémi vett részt. A 3D képeket Bödőcs András állította össze. Az ásatásban és a feldolgozásban még a következő BA hallgató vettek részt: Kapitány Regina, Almády László, Kovács Sára és Pillik Bertalan.
} 
Kalla Gábor - Dezső Tamás • Magyar ásatások iraki Kurdisztán hegyei között

Dezsö, T., 2016b.

The arrowheads from Grd-i Tle (Rania Plain, Iraqi Kurdistan). Dissertationes Archaeologicae Ser. 3(4), pp. 97-112. doi: http://dx.doi.org/10.17204/dissarch.2017.97

Dezsö, T., Kalla, G., Mordovin, M., Masek, Z., Szabó, N., et al., 2016.

Grd-i Tle 2016. Preliminary report of the Hungarian Archaeological Mission of the Eötvös Loránd University to Grd-i Tle (Saruchawa) in Iraqi Kurdistan. Dissertationes Archaeologicae Ser. 3(4), pp. 233-240. doi: http://dx.doi.org/10.17204/dissarch.2015.233

Dezső, T., Kalla, G., Baiz Ismail, B., Bödöcs, A., FülöP, K., ET Al., 2017.

Preliminary report on the Hungarian Archaeological Mission (Eötvös Loránd University) at Grd-i Tle (Saruchawa) in Iraq. Second Season (2017). Dissertationes Archaeologicae Ser. 3(5), pp. 361-392. doi: http://dx.doi.org/10.17204/dissarch.2017.361

Dezsö, T. \& Mordovin, M. 2016.

The first season of the excavation of Grd-iTle. The Fortications of Grd-iTle (Field 1). Dissertationes Archaeologicae Ser. 3 (4), pp. 241-262. doi: http://dx.doi.org/10.17204/dissarch.2015.241

Kalla, G. \& Dezsö, T., 2019.

The Hungarian excavations at Grd-i Tle (Ranya-Plain). In: Z. Bradosty, A. Zibae, H. A. Abdulrahman, M. O. Aziz, \& Ğ. 'at Șalah ad-Dīn, szerk., Proceedings of the 3rd International Scientific Conference Archaeology and Heritage in Kurdistan. Erbil: Salahaddin University, pp. 630-645.

KIRÁLY, A., 2017.

Grd-i Tle knapped and ground stone artefacts, excavation seasons 2016-2017. Dissertationes Archaeologicae Ser. 3 (5), pp. 83-96. doi: http://dx.doi.org/10.17204/dissarch.2017.83

MacGinnis, J., Wicke, D., \& Greenfield T., EDS., 2016.

The Provincial Archaeology of the Assyrian Empire. Cambridge: Oxbow Books.

MAsek, Z., \& Mordovin, M., 2016A.

The first season of the excavation of Grd-iTle. The post-medieval settlement at Grd-i Tle (Field1). Dissertationes Archaeologicae Ser. 3(4), pp. 277-289. doi: http://dx.doi.org/10.17204/dissarch.2015.277

MaseK, Z,. \& Mordovin, M., 2016в.

Az Oszmán Birodalom végvidékén... Irakban. Várak, kastélyok,templomok 12(1), pp. 120-122.

Miglus, P. M., 1999.

Städtische Wohnarchitektur in Babylonien und Assyrien. Baghdader Forschungen 22. Mainz: von Zabern.

NAUMANN, R., 1971.

Architektur Kleinasiens von ihren Anfängen bis zum Ende der hethitischen Zeit. Tübingen: Wasmuth.

RADNER, K., 2016.

The Peshdar Plain in the Neo-Assyrian period: the Border March of the Palace Herald. In: K. Radner, J. F. Kreppner, \& A. Squitieri, szerk., Exploring the Neo-Assyrian Frontier with Western Iran. The 2015 Season at Gird-i Bazar and Qalat-i Dinka. Peshdar Plain Project Publications 1. Gladbeck: PeWe Verlag, pp. 17-22. 